УДК 616.379-008.64

DOI 10.11603/2411-1597.2019.1.9989

\title{
ЦУКРОВИЙ ДІАБЕТ
}

\author{
I. М. Щеголь
}

\section{ДВНЗ «Тернопільський державний медичний університет імені І. Я. Горбачевського МОЗ України»}

У статті висвітлено типи, симптоми і діагностику цукрового діабету.

\section{DIABETES MELLITUS}

\section{M. Shchegol}

\section{Horbachevsky Ternopil State Medical University}

The article outlines the background, types, symptoms and diagnostic technics of diabetes mellitus.

Вступ. На даний час цукровий діабет посідає одне з головних місць у структурі ендокринної патології. Він належить до однієї з головних дослідно-наукових та соціально-медичних проблем. Ця проблема пов'язана з поширенням цукрового діабету, зростанням захворювань на цю патологію та з тяжкими діабетичними ускладненнями. Кількість хворих на цукровий діабет постійно збільшується, що вказує на глобальну епідемію в усьому світі. Науковці прогнозують, що цукровий діабет у XXI столітті буде хворобою, яка скорочуватиме життя в глобальному масштабі.

Мета статті - висвітлити типи цукрового діабету, розкрити причини його виникнення та діагностику.

Проведене дослідження наукових робіт дозволяє зробити висновок, що ця тема $є$ актуальною на сьогодні, $\epsilon$ велика кількість наукових досліджень з цієі теми, але спостерігають відсутність єдиного підходу до встановлення причин виникнення цукрового діабету.

Типи цукрового діабету, причини його виникнення та діагностику досліджували у роботах багатьох авторів, а саме: П. М. Боднар, М. Ф. Гриненко, В. Г.Баранова, У. Г. Баранов, М. В. Степашко, В. К. Добровольський, В. А. Кальніболоцький та інших.

Основна частина. Цукровий діабет є поширеним хронічним захворюванням, коли рівень глюкози в крові зростає внаслідок порушення продукції інсуліну або нечутливості до нього, тобто спостерігають неповне перетворення глюкози в енергію. Це захворювання призводить до великої кількості серйозних проблем зі здоров'ям [7].

с І. М. Щеголь, 2019
Типи цукрового діабету наведено на рисунку 1.

Найчастіше з наведених шести типів цукрового діабету в клінічній практиці спостерігають 1 та 2 типи.

На прикладі досліджень, проведених в одній 3 київських міських лікарень, що обслуговує три райони м. Києва, за 2017 р. у відділенні гастроентерології з ендокринними ліжками проліковано 378 пацієнтів із діагнозом - цукровий діабет. У відділення госпіталізовують пацієнтів у плановому порядку, з поліклінік та за направленням. Проходять планові обстеження та лікування засобами, що впливають на травну систему і метаболічні процеси, препаратами вітамінів групи В.

Інсулінозалежний цукровий діабет (1 тип) в прогностичному плані $є$ найсерйознішим, він починається з дитячого або підліткового віку. Підшлунковою залозою виробляється недостатня кількість інсуліну або він повністю відсутній. У клітинах підшлункової залози, які виробляють інсулін, відбуваються зміни, спричинені генетичними механізмами, чинниками навколишнього середовища та вірусними інфекціями, які дитина чи підліток перенесли. Ці фактори можуть призвести до руйнування клітин підшлункової залози. При веденні пацієнтом здорового способу життя, дотриманні всіх рекомендацій лікарів, профілактичному лікуванні в стаціонарі зменшується ризик виникнення ускладнень ЦД та підвищується якість життя.

Пацієнтів із 1 типом цукрового діабету в Київській міській клінічній лікарні було проліковано в кількості 247 осіб. 


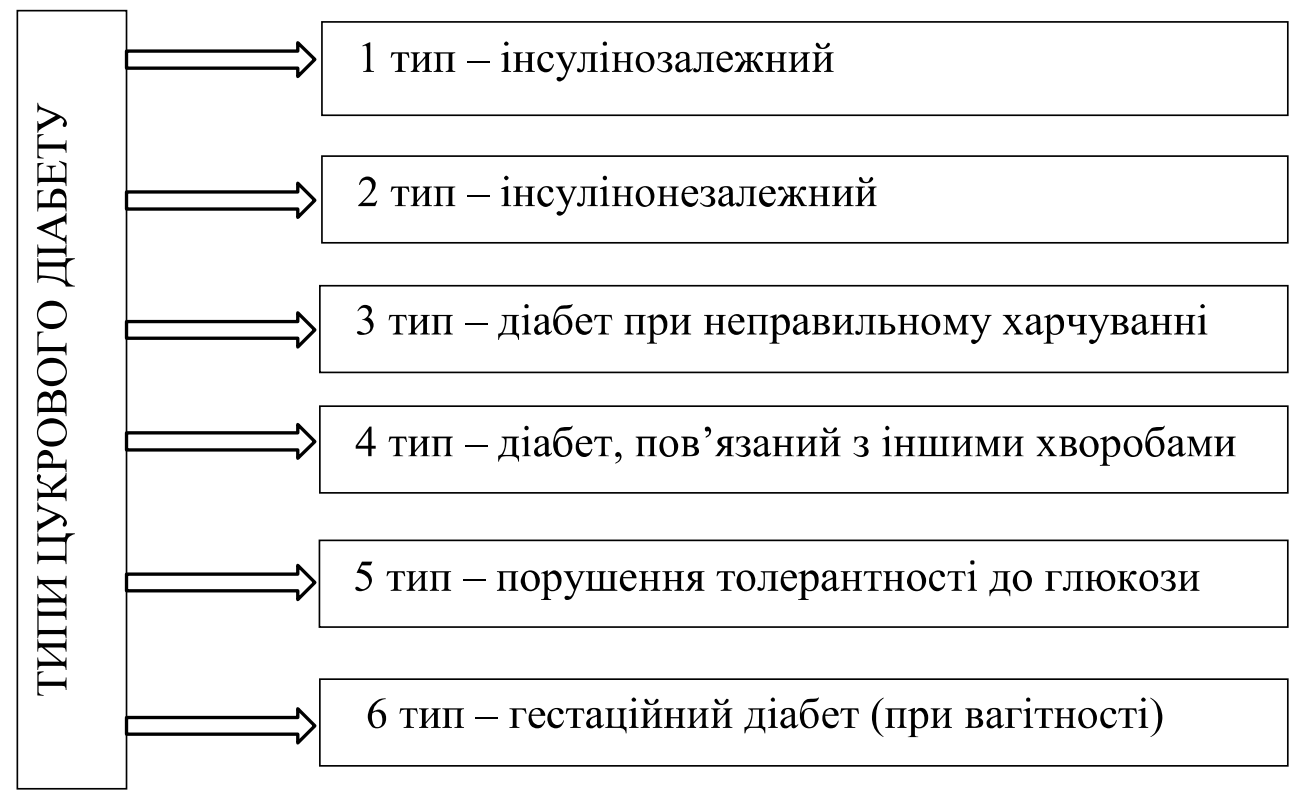

Рuc. 1. Типи цукрового діабету.

Інсулінонезалежний цукровий діабет (2 тип) спостерігають майже у 90-95\% хворих, його діагностують у дорослих старше 40 років. Підшлункова залоза виробляє достатню кількість інсуліну, але клітини організму не реагують належним чином, оскільки вони $\epsilon$ резистентними до інсуліну. Цей тип цукрового діабету виникає поступово, часто його діагностують випадково при періодичному обстеженні чи стає «знахідкою» при перебуванні пацієнта на стаціонарному лікуванні з будь-яким іншим захворюванням.

Пацієнтів із 2 типом цукрового діабету проліковано в кількості 131.

Науковцями встановлено, що цукровий діабет генетично передається. Приблизно у 5 \% випадків цукровий діабет 1 типу передається від батька та майже у $10 \%$ - від матері. Якщо на цукровий діабет хворіють обоє батьків, то ризик захворюваності дитини сягає $70 \%$ [5].

При захворюванні на цукровий діабет 2 типу матері або батька, то ризик захворювання дитини становить $80 \%$. Якщо хворіють обоє батьків, то ризик захворюваності дитини становить майже $100 \%$.

Симптоматика діабету 1 та 2 типів різна.

Ознаки цукрового діабету 1 типу:

- спрага;

- запах ацетону з рота;

- часте сечовипускання;

- погане загоєння ран;

- свербіж шкіри.

Цей тип цукрового діабету розвивається швидко, симптоми проявляються декілька днів та можуть призвести до діабетичної коми. Діабетична кома - це стан, який розвивається внаслідок нестачі інсуліну в організмі людини, підшлункова залоза перестає його виробляти.

Ознаки цукрового діабету 2 типу:

- підвищена втомлюваність;

- погіршення гостроти зору;

- провали та погіршення пам'яті;

- схильність до інфекційних хвороб;

- кандидоз;

- спрага;

- виразки на ногах.

Цей тип цукрового діабету небезпечний тим, що він довго не проявляється, і діагноз встановлюють пізніше.

Для виявлення цукрового діабету необхідно провести дослідження, які наведено на рисунку 2.

Діагноз захворювання на цукровий діабет було встановлено в тому випадку, якщо [6]:

- рівень глюкози в крові 11 ммоль/л і більше та наявні симптоми захворювання;

- рівень глюкози в крові натще 6,9 ммоль/л та більше; - рівень глюкози в крові 11 ммоль/л та більше, через 2 год після тесту на толерантність до глюкози.

Для уточнення діагнозу визначають глікозильований гемоглобін, який відображає рівень глюкози в крові протягом останніх 2-3 місяців.

Вчасно встановлений діагноз дозволяє нормалізувати порушений вуглеводний обмін, знизити концентрацію глюкози в крові, що робить можливою профілактику ускладнень від цієї хвороби. 


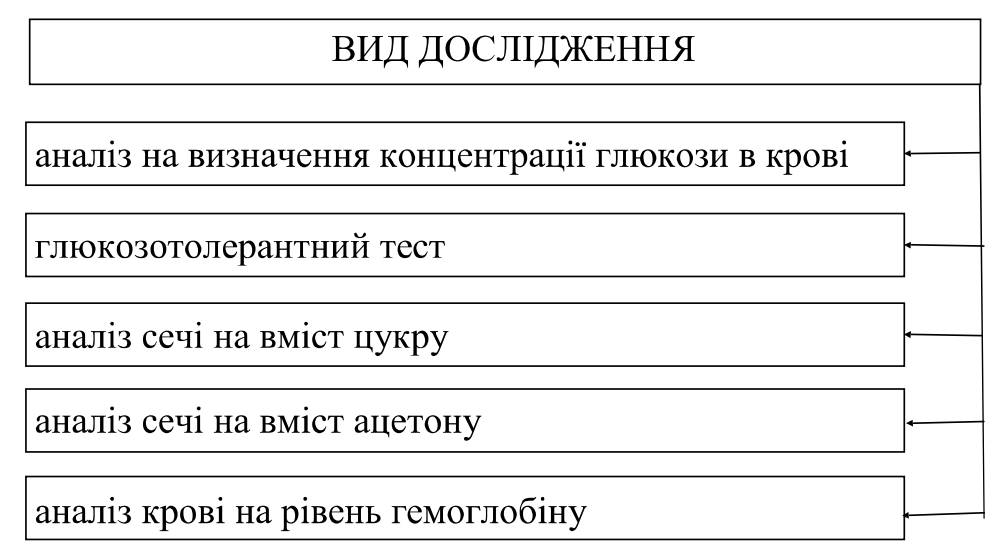

Puc. 2. Види досліджень для виявлення цукрового діабету.

На даний час вилікувати захворювання на цукровий діабет неможливо. Головною метою лікування $\epsilon$ зниження рівня глюкози в крові (1 тип - регулярні ін'єкції інсуліну, 2 тип - призначають цукрознижувальні препарати та дієту) [3].

Висновки. Цукровий діабет - це масштабне хронічне захворювання в структурі ендокринної патології.

\section{СПИСОК ЛІТЕРАТУРИ}

1. Аметов А. С. Цукровий діабет: причини і ознаки / А. С. Аметов, Г. С. Зефірова // Твоє здоров'я. - 1990. - 133 с.

2. Астамирова Х. С. Настольная книга диабетика / Х. С. Астамирова. - М. : Изд-во Эксмо, 2004. - 320 с.

3. Балаболкин М. И. Лечение сахарного диабета и его осложнений : [учеб. пособ.] / М. И. Балаболкин, Е. М. Клебанова, В. М. Креминская. - М. : ОАО «Издательство «Медицина», 2005. - 242 с.

4. Боднар П. М. Ендокринологія : підручник для студентів вищих медичних навчальних закладів / П. М. Боднар ; за ред. проф. П. М. Боднара. - Вінниця : Нова Книга, 2010. -64 c.
Він потребує вчасного діагностування та постійного лікування. Метою лікування цього захворювання $\epsilon$ контроль і регуляція рівня глюкози в крові для збереження якості та тривалості життя, зменшення прояву симптомів і запобігання ускладненням.

5. Бокарев И. Н. Сахарный диабет : руководство для врачей / И. Н. Бокарев, Б. К. Беликов, О. И. Шубина. - М. : ООО «Медицинское информационное агенство», 2006. - 400 с.

6. Сахарный диабет. Диагностика, лечение, профилактика / под ред. И. И. Дедова, М. В. Шестаковой. - М., 2011. - 361 c.

7. Скачко Б. Г. Цукровий діабет: хвороба століття, чи розплата за легковажність? / Б. Г. Скачко, Г. О. Орещук. - К. : Здоров'я, 2012. - 96 с.

8. Чернобров А. Д. Цукровий діабет в Україні та його ускладнення / А. Д. Чернобров // Матер. I нац. конгрес «Человек и лекарство - Украина», 2008. - С. 108-109. 